\title{
Kayseri Zincidere Hilâl-i Ahmer Nekahethanesi/Şifa Yurdu'nun Faaliyetleri (1916-1918)
}

\author{
Mustafa Sarı ${ }^{*}$ - Furkan Taşcı ${ }^{* *}$
}

(ORCID: 0000-0003-0883-1995/ 0000-0002-5493-2036)

\author{
Makale Gönderim Tarihi \\ 07.07.2021
}

\author{
Makale Kabul Tarihi \\ 25.09.2021
}

\section{Atıf Bilgisi/Reference Information}

Chicago: Sarı, M., Taşcl, F., "Kayseri Zincidere Hilâl-i Ahmer Nekahethanesi/Şifa Yurdu'nun Faaliyetleri (1916-1918)", VakanüvisUluslararası Tarih Araştırmaları Dergisi, 6/2 (2021): 839-868.

APA: Sarı, M., Taşcı, F. (2021). Kayseri Zincidere Hilâl-i Ahmer Nekahethanesi/Şifa Yurdu'nun Faaliyetleri (1916-1918). VakanüvisUluslararası Tarih Araştırmaları Dergisi, 6 (2) , 839-868.

\section{Öz}

I. Dünya Savaşı yıllarında Hilâl-i Ahmer Cemiyeti tarafından yaralı ve hasta askerlere yardım amacıyla hastane, nekahethane şifa yurdu gibi kurumlar açılmıştır. Bu amaçla açılan kurumlardan birisi de, Kafkas Cephesi'ne yakın olan Kayseri'nin Zincidere mahallinde kurulan Zincidere Hilâl-i Ahmer Nekahethanesi/Şifa Yurdu'dur. Illk önce Erzurum'da açılan bu kurum, savaş sırasındaki geri çekilme nedeniyle sırasıyla Erzincan, Kemah ve Kayseri'ye nakledilmiştir. 2.000 yataklı kapasitesiyle bölgenin en büyük sıhhî kurumlarından birisi olan Zincidere Nekahethanesi/Şifa Yurdu, askerlerin dışında savaş sırasında memleketlerini terk etmek zorunda kalan mültecilere,

* Doç. Dr., Sakarya Üniversitesi Fen-Edebiyat Fakültesi Tarih Bölümü, Türkiye, msari@sakarya.edu.tr.

Assoc. Prof. Dr. Sakarya University Faculty of Arts and Sciences Department of History, Turkey.

** Yüksek Lisans Öğrencisi, Sakarya Üniversitesi Sosyal Bilimler Enstitüsü Tarih ABD T.

C. Tarihi Bilim Dalı, furkan.tasci@ogr.sakarya.edu.tr.

MA Student, Sakarya University Institute of Social Sciences Main Discipline of History Discipline of the History of the Republic of Turkey, Turkey.

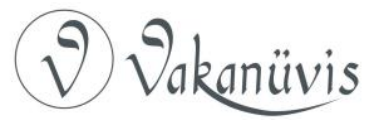


kimsesiz çocuklara ve bölge insanına hem sıhhî hem de insanî önemli yardımlarda bulunmuştur

Bu çalışmada başta Kızılay Arşivi olmak üzere Osmanlı Arşivi, raporlar ve ikinci el kaynaklar incelenerek bu Zincidere Hilâl-i Ahmer Nekahethanesi/Şifa Yurdu'nun cephe gerisinde sıhhî ve diğer alanlardaki faaliyetleri ele alınacaktır.

Anahtar Kelimeler: Hilâl-i Ahmer Cemiyeti, Kayseri, Zincidere Nekahethanesi/Şifa Yurdu, Kafkas Cephesi

The Activities of Kayseri Zincidere Hilal-i Ahmer (Red Crescent) Convalescence/ Healing Dormitory (1916-1918)

\section{Abstract}

During the First World War, institutions like hospitals, convalescence and healing houses were established by the Red Crescent Society to help the wounded and sick soldiers. One of the institutions founded for this purpose was the Zincidere Hilal-i Ahmer Convalescence/Healing House, established in Zincidere, Kayseri, which is close to the Caucasian Front. This institution, first set up in Erzurum, was transferred to Erzincan, Kemah and Kayseri, respectively, due to the withdrawal during the war. Zincidere Hilal-i Ahmer Convalescence/Healing House, one of the largest sanitary institutions in the region with its 2,000-bed capacity, has served not only the soldiers, but also the refugees and orphans who had to leave their homeland during the war and the people of the region, not only in the sanitary field, but also in the humanitarian field.

The aim of this study is to discuss the activities of Zincidere Convalescence/Healing House behind the front by means of the documents from especially the Red Crescent Archive, the Ottoman Archive, reports and related literature.

Keywords: The Ottoman Red Crescent Society, Kayseri, Zincidere Convalescence/Healing House, the Caucasian Front

\section{Giriş}

Jean Henry Dunant'ın fikirleriyle ortaya çıkan Salîb-i Ahmer (Kızılhaç), İslam Dünyası'nda Hilâl-i Ahmer olarak adlandırılmıştır. Dunant'ın fikri, savaşta yaralanan ve hastalanan insanların can ve 
hukuksal haklarını tarafsız bir yapıyla koruma altına almaktı. ${ }^{1}$ Bu fikri hayata geçirmek isteyen Dunant ve arkadaşları, 9 Şubat 1863 tarihinde Cenevre'de toplanan "Beşler Komitesi" adıyla bir yapı oluşturmuştu. İlerleyen dönemde "Uluslararası Yaralılara Yardım Komitesi" adını alan bu yapı, ilk toplantısını 17 Şubat 1863 yılında yine Cenevre'de gerçekleştirmiştir².

26-29 Ekim 1863 tarihleri arasında Cenevre'de Avrupa'dan 16 ülkenin katılım sağladığı bir konferansla ilk uluslararası adım atılmış oldu. ${ }^{3} 8$ Ağustos 1864 'de yine 16 devletin katıldığı yeni bir konferansla, ilkyardım teşkilatı, hastaneler ve gönüllü sağlık çalışanları ile sivil halk ve yaralılara yapılacak yardımları içeren 22 Ağustos 1864 tarihli Cenevre Sözleşmesi imzalandı ${ }^{4}$. Böylece Kızılhaç Teşkilatı, resmi olarak kurulmuş oldu ve sözleşmeyi imzalamak için devletlere bir yıl süre tanınd $1^{5}$.

Osmanlı Devleti, 5 Temmuz 1865 tarihinde Cenevre Sözleşmesi'ni imzalamıştır ${ }^{6}$. Mekteb-i Tıbbiye Muallimi Dr. Abdullah Bey, Kızılhaç benzeri müessesenin Osmanlı topraklarında da kurulması gerekliliğini görerek girişimlere başlamıştır. Dr. Abdullah Bey, Marko ve Ömer Paşaların da desteği ile 11 Haziran 1868'de "Asakir-i Berriye ve Bahriye Mecruhinine Muavenet Cemiyeti" adı altında bir teşkilat kurmuştur?. Bu cemiyet, Hilâl-i Ahmer'in ilk hali sayılmaktadır.

II. Abdulhamid, yayınladığı bir irade ile cemiyeti kendi himayesine almış ve cemiyetin adının "Osmanlı Hilâl-i Ahmer Cemiyeti" olduğunu ilan etmiştir. 14 Nisan 1877 'de yapılan bir toplantı ile cemiyet resmen

\footnotetext{
${ }^{1}$ Mesut Çapa, Kızılay (Hilâl-i Ahmer) Cemiyeti, Türkiye Kızılay Derneği Yayınları, Ankara 2009, s. 9.

2 Hüsnü Ada, Osmanlı Devletinin Hizmetinde Illk Modern Osmanlı Sivil Toplum Örgütü: Osmanlı Hilâl-i Ahmer Cemiyeti (1868-1911), Basılmamış Doktora Tezi, Marmara Üniversitesi Türkiyat Araştırmaları Enstitüsü, İstanbul 2011, s. 3.

3 Türkiye Hilâl- $i$ Ahmer Cemiyeti Merkez-i Umumisi Tarafından 1339 Senesi Hilâl- $i$ Ahmer Meclis- i Umumisine Takdim Edilen (1335- 1338) Dört Senelik Devreye Ait Rapor, Matbaa-i Ahmed ìnsan ve Şürekâsı, İstanbul, 1339, s. 282.

${ }^{4}$ Çapa, Kızılay (Hilâl-i Ahmer) Cemiyeti, s. 10.

5 Osmanlı Hilâl-i Ahmer Cemiyeti Salnamesi (1329-1331), Matbaa-i Ahmet İhsan ve Şürekâsı, ìstanbul, (t.y), s. 5.

${ }^{6}$ Osmanlı Hilâl-i Ahmer Mecmuası, 15 Eylül 1337/1921, Sayı: 1, s. 17-18.

${ }^{7}$ Ada, Osmanlı Hilâl-i Ahmer Cemiyeti (1868-1911), s. 11-15.
}

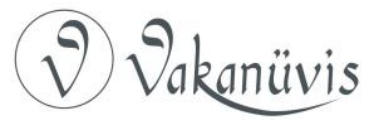


kurulmuştur ${ }^{8}$. Cemiyet, Rusya ile yapılan 1877-1878 savaşlarında faydalı işlerde bulunsa da II. Abdulhamid dönemi boyunca genelde atıl bir vaziyette kalmıştır ${ }^{9}$.

II. Meşrutiyet'in ilanı ve Sadrazam Hakkı İbrahim Paşa'nın çabalarıyla Hilâl-i Ahmer Cemiyeti 20 Nisan 1911 tarihinde düzenlenmiş ve görevine devam etmiştir ${ }^{10}$. Cemiyet, bu tarihten itibaren Osmanlı topraklarının hemen hemen her köşesinde şubelerini açmaya başlamıştır. Özellikle I. Dünya Savaşı́nda cemiyetin teşkilatlanma süreci hızlanmıştır.

I. Dünya Savaşı'na kadar Hilâl-i Ahmer Cemiyeti tarafından Trabzon, İzmir, İzmit gibi önemli vilayetlerde şubeler teşekkül edilmişti. Kayseri'de bulunduğu konum nedeniyle teşekkül edilen önemli şubelerden birisiydi. 1915 Nisan-Mayıs aylarında Belediye Reisi Rıfat Bey'in öncülüğünde kurulan bu şubenin yönetim heyetini Tüccar İbrahim Efendi, Meclis-i Umumi Kâtibi Nurullah Efendi, Tüccar Yedekçizade Hüseyin Bey, Tüccar Hafız Ağazade Hayrullah Efendi, Tüccar Katibzade Nuh Efendi ve Tüccar Şişlizade Lütfü Efendi oluşturmaktaydı ${ }^{11}$. Hilâl-i Ahmer Cemiyeti Kayseri Şubesi böylece faaliyete geçmişti.

Hilâl-i Ahmer Cemiyeti'nin Kayseri ve civarındaki faaliyetleri asıl olarak Erzurum'da bulunan Hilâl-i Ahmer Nekahethanesi'nin Kayseri yakınlarındaki Zincidere'ye taşınması ile başlayacaktır. Nekahet kelime anlamı olarak "hastalıktan sonraki zayıflık", nekahethane ise prevantoryum yani "verem mikrobunu kapmış ama henüz hastalığa yakalanmamış zayıf vücutlu kimselerin vereme yakalanmasını önlemek için bakıldıkları sağlık kurumu" anlamına gelmektedir ${ }^{12}$. Buradan anlayacağımız üzere kurumun öncelikli amaçları hasta ve yaralı askerlerin tedavisi ile bölgedeki ve askeriyedeki salgın hastalıklarla

\footnotetext{
8 Osmanlı Hilâl-i Ahmer Cemiyeti Salnamesi, s. 27-29.

${ }^{9}$ Çapa, Kızılay (Hilâl-i Ahmer Cemiyeti), s. 12.

10 Osmanlı Hilâl-i Ahmer Cemiyeti Salnamesi, s. 34-36; Besim Ömer, Hanımefendilere Hilâl-i Ahmer'e Dair Konferans, Ahmet ihsan ve Şürekâsı Matbaacılık Osmanlı Şirketi, İstanbul 1330, s. 20-21.

11 KA, 28/123, lef:1.

${ }^{12}$ Ferit Develioğlu, Osmanlıca-Türkçe Ansiklopedik Lûgat, Aydın Kitabevi, 2013, 960.
}

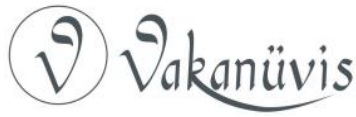


mücadele etmektir. I. Dünya Savaşı sonuna kadar kurumun öncelikli amaçları bunlar olmuştur.

Ancak şunu da belirtmek gerekir ki Mart 1917 yılı içerisinde kurumun ismi "Zincidere Hilâl-i Ahmer Şifa Yurdu" olarak değişmiştir. Ancak bu tarihten önce de bazı belgelerde "Şifa Yurdu" ifadesine rastlamak mümkündür. Bunun dışında yine bazı belgelerde "Zincidere Hilâl-i Ahmer Hastanesi" ifadesini görmekteyiz. Bu nedenle bu çalışmada bu kurum için hastane, nekahethane ve şifa yurdu tabirleri kullanılmıştır.

\section{Zincidere Hilâl-i Ahmer Nekahethanesi'nin Kurulması ve illk Faaliyetleri}

I. Dünya Savaşı sırasında Kafkas Cephesi'nin de açılması ile birlikte bu cephede bir sıhhî heyetin görevlendirilmesi lüzumu ortaya çıkmıştı. Bunun üzerine Hilâl-i Ahmer Cemiyeti, bölgeye bir sıhhî heyeti göndermiş ve bu heyet de Erzurum'da 500 yataklı bir nekahethane açmıştı ${ }^{13}$. Ancak Sarıkamış harekatının başarışız olması ve Rusların karşı taarruzları durdurulamadığından sıhhî heyet, 100 yataklık ekipman ile birlikte bir sağlık ekibini Erzurum'da bırakarak Erzincan'a çekilmek zorunda kalmıştır ${ }^{14}$. Erzincan'da hastane için müsait bir bina olmadığı için süvari kışlasında 3 ay kadar faaliyet göstermiştir ${ }^{15}$. Bu arada Rusların Erzurum'u işgali üzerine heyet nekahethaneyi Kemah'a nakletmişti ${ }^{16}$. Kemah'ta faaliyete başlayan hastane, kısa bir süre sonra ordu tarafından görülen lüzum üzerine Mayıs 1916 ortalarında Kayseri'ye nakledilme emrini almıştı.

Hastane Sertabibi Burhaneddin Bey, emri alır almaz nakil hazırlıklarına başlamıştı. Mayıs 1916 başlarında hastanenin hasta mevcudu 1.200 civarındaydı. Bunlardan 49'u vefat etmiş, 210 asker taburcu olmuş 49 asker hava değişikliği nedeniyle başka yerlere sevk edilmişti. Nakil sırasındaki zorluklardan dolayı 520 hasta Harput Hastanelerine $^{17}$, eşya ve erzakın bir kısmı ise Erzincan Hilâl-i Ahmer

\footnotetext{
13 Osmanlı Hilâl-i Ahmer Mecmuası, (15 Teşrin-i Sani 1337/1921), Sayı:3, s. 61.

${ }^{14}$ Çapa, Kızılay (Hilâl-i Ahmer Cemiyeti), s. 82.

15 Murat Uluğtekin, M. Gül Uluğtekin, Osmanlı'dan Cumhuriyet'e Hilâl-i Ahmer Icraat Raporları 1914-1928, Türk Kızılayı Yayınları, Ankara, 2013, s. 13.

${ }^{16}$ Çapa, Kızılay (Hilâl-i Ahmer Cemiyeti), s. 82.

$17 \mathrm{KA}, 633 / 21$.
}

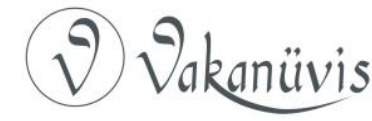


Hastanesi'ne devredilmişti ${ }^{18}$. Böylece nakil daha az hasta ve malzeme ile gerçekleşecekti.

Hazırlıkların tamamlanmasıyla beraber Hilâl-i Ahmer Hastanesi, Sertabip Burhaneddin Bey'in başkanlığında memurlar ve hasta askerlerle birlikle 26 Mayıs 1916'da Kemah'tan hareket etmiştir ${ }^{19}$. Yol güzergâhı Kemah-Divriği-Sivas-Kayseri olarak belirlenmişti. Divriği'ne ulaşan heyet burada belli bir müddet dinlendikten sonra Sivas'a doğru harekete geçmiştir. Sivas'a ulaşan heyet, buraya gelene kadar ki masrafı olan 7.100 kuruşu kendi kasasından ödemiştir ${ }^{20}$. Sivas'tan Kayseri'ye heyet, hayvanlarla nakliyeyi gerçekleştirecekti. Hayvanlar için 514 kuruş harcanması hesaplanmıştı ${ }^{21}$.

Hilâl-i Ahmer Heyeti, toplamda 19-20 günlük bir yolculuğun ardından nihayet 15 Haziran 1916'da Kayseri'ye ulaşmıştır. Burada Hilâl-i Ahmer Hastanesi'nin faaliyet göstermesi için belirlenen TalasZincidere köyündeki Amerikan Eytamhanesi, Sertabib Burhaneddin Bey tarafından devralınmıştı ${ }^{22}$. Kayseri'ye $15 \mathrm{~km}$ uzaklıkta olan ve yaklaşık 500 yatak kapasitesine sahip bu eytamhanenin hastane olarak hizmet vermesi Hilâl-i Ahmer Heyeti'nin ciddi bir hazırlık yapması gerekliydi. Çünkü uzun zamandır boş bir halde bulunan binanın öncelikle tamirata ve daha sonra eşyalarının tamamlanmasına ihtiyaç vardır. Binanın tamirat ve boya işleri hastane görevlileri tarafından yapıldığı için tadilata çok fazla para sarf edilmemiştir. Binanın tadilatı sona erdikten sonra çamaşırhane ve mutfak inşaatı ile meşgul olunmuştur. Daha sonra da eşya tedariki ile ilgilenilmiştir. Ancak Amerikan Mektebi'nden kalan çoğu eşya, heyet buraya gelmeden önce Talas Şifa Yurdu'na verildiğinden, binada sıra haricinde bir şey bulunmamaktaydı. Bu nedenle iş yine hastane görevlilerine düşmüştü. Illk etapta 500 karyola 500 yatak yüzü hazırlanması gerekliydi.

Burhaneddin Bey, Zincidere'de bulunan Rum metropoliti ile de görüşerek mektepte bulunan 100 karyola ile tabak, kaşık ve kazan gibi eşyaların alınmasını sağlamıştı. Ayrıca kurum marangozları mektepte

\footnotetext{
$18 \mathrm{KA}, 315 / 18$.

$19 \mathrm{KA}, 633 / 24$.

${ }^{20} \mathrm{KA}, 402 / 67$.

${ }^{21} \mathrm{KA}, 402 / 61$ lef:1.

$22 \mathrm{KA}, 315 / 18$.
}

\section{(V) Vakaniuvis}


bulunan sıralardan 208 karyola yapmıştı. Bunların dışında, 150 hasta gömleği ve 300 çift çorap tedariki sağlanmıştır. Hastane görevlileri için de 20 takımı kurumca yapılmak üzere 80 takım elbise, 500 çift hasta terliği ve 100 çift yemeni tedarik edilmiştir. Erzak ihtiyacını karşılamak üzere Kayseri'den 6 kuruş 25 paraya et, 60 paraya ekmek ve 31 kuruşa yağ tedariki konusunda anlaşılmıştır. Ayrıca Kayseri'de ve Zincidere bölgesinde bulunması mümkün olmayan odun için Sivas vilayetinde bulunan Aziziye kaymakamlığına müracaat edilmiştir. Yine Sivas'tan 500 bin kıyye odun siparişi kurum tarafından verilmiştir. Bu hummalı hazırlıklardan sonra Sertabip Burhaneddin Bey, 6 Temmuz'da 150 hasta ile faaliyete geçilebileceğini tasarlamaktaydı ${ }^{23}$. Hilâl-i Ahmer Zincidere Nekahethanesi'nin hazırlıklarının tamamlanmasında Kayseri Hilâl-i Ahmer Şubesi'nin de yardımları olmuştu. Nekahethanenin eksiklileri farklı kişiler tarafından tamamlanmıştı ${ }^{24}$.

Hilâl-i Ahmer Zincidere Nekahethanesi, bina hazırlıklarını ve diğer eşya ile malzeme eksikliklerini tamamlarken, diğer taraftan personel eksiklikleri ile de uğraşmaktaydı. Nekahethane İdare Memurluğuna tayin edilen Kenan Bey, 9 Temmuz günü Kayseri'ye gelmişti. Sertabip Burhaneddin Bey, Kenan Bey'e vazifesini devir-teslim ettikten sonra Doktor Mustafa Bey'e sertabip vekâleti görevini vererek, vazifeden ayrılmayı düşünmekteydi. Nitekim Burhaneddin Bey, 9 Temmuz 1916 tarihinde Hilâl-i Ahmer Merkez-i Umumisi'ne gönderdiği bir yazıda, nekahethanenin idari işlerinin düzenlendiğini, yataklarının hazırlandığını ve hasta dâhi kabul edildiğini belirtmişti. Burhaneddin Bey ayrıca nekahethanenin bu noktaya gelmesinde çok büyük gayretleri olan ve bütün işlere vakıf olan Mustafa Bey'in sertababete ve vekilharç muavini olan Kadir Fehmi Efendinin de vekilharçlığa tayinlerini talep etmişti ${ }^{25}$.

Burhaneddin Bey'in sertabiblik görevinden ayrılmasının üzerine, Zincidere Şifa Yurdu'nun bağlı olduğu III. Ordu Sıhhîye Reisi Tevfik Salim Bey, Hilâl-i Ahmer Merkezi'ne 13 Temmuz 1916 tarihinde bir telgraf göndererek şifa yurdunun tesisin tamamlanması için yeni bir

\footnotetext{
$23 \mathrm{KA}, 315 / 28$.

${ }^{24}$ BOA, DH.I.UM.EK. 16/ 78, lef: 2.

${ }^{25} \mathrm{KA}, 315 / 34$.
}

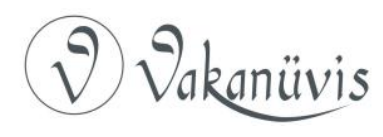


sertabibin süratle tayin edilerek gönderilmesini istemişti ${ }^{26}$. Tevfik Bey ayrıca Şifa Yurdu sertabibinin gelene kadar da yurda ambar memurlarından Salih Beyin vekâleten idare etmesini uygun görmüştü ${ }^{27}$.

Zincidere Şifa Yurdu personelinin en önemli sorunlarından birisi de maaşlarıydı. İdare Memuru Kenan Bey de Seferberlik bidayetinden beri aldığı maaşın kendisine yetmediğini ileri sürerek ve Hilâl-i Ahmer bünyesinde çalışan diğer kişileri örnek göstererek 12 lira olan maaşının 15 liraya çıkarılmasını istemiştir ${ }^{28}$. Kenan Bey ayrıca Zincidere Nekahathanesi'nin tesisini tamamlamak için 1.000 lira havale istemiştir ${ }^{29}$.

Bu arada III. Ordu Sıhhîye Reisi Tevfik Salim Bey, Zinciderede Hilâl-i Ahmer Nekahethanesinin kapasitesinin 1.000 yatağa çıkarttırılarak, yeni eklenen 500 yatağın sıtmalılar ve frengililere tahsisini uygun görmekteydi. Salim Bey, 22 Ağustos 1916 tarihinde Hilâl-i Ahmer Riyaseti'nden Nekahethane sertabibine bu yönde emir verilmesini istemiştir ${ }^{30}$. Ancak Eylül ortalarına gelindiğinde hala ek 500 yatağın Zincidere Nekahethanesine gönderilmediği ortaya çıkmıştı. Tevfik Salim Bey, Hilâl-i Ahmer Riyaseti'ne bu kez 17 Eylül'de yeni yazı göndererek bu yatakların acilen gönderilmesini istemiştir ${ }^{31}$.

Eylül 1916 ayı ortalarına doğru Burhaneddin Bey'in yerine nekahethane sertabibi olarak İsmail Hakkı Bey'in atandığı görülmektedir. İsmail Hakkı Bey, Kayseri'ye gelir gelmez Zincidere Nekahethanesinin çok ciddi bir personel sorunu olduğunu görmüştü. İsmail Hakkı Bey'in vazifeye başladığı sıralarda Kayseri Nekahethanesi'nde maaş alan memur ve doktorlar şu şekildeydi:

\begin{tabular}{|l|l|r|}
\hline \multicolumn{1}{|c|}{ İsim } & \multicolumn{1}{|c|}{ Görevi } & Maaş - (Kuruş) \\
\hline Mustafa Efendi & Doktor & 1500 \\
\hline İsmail Efendi & İnzibat Zabiti & 300 \\
\hline
\end{tabular}

\footnotetext{
${ }^{26} \mathrm{KA}, 714 / 94$.

$27 \mathrm{KA}, 714 / 88$.

$28 \mathrm{KA}, 315 / 51$.

${ }^{29} \mathrm{KA}, 315 / 46$.

${ }^{30} \mathrm{KA}, 714 / 87$.

${ }^{31} \mathrm{KA}, 714 / 80$.
}

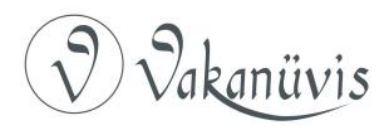




\begin{tabular}{|l|l|r|}
\hline Hasibe Hanım & Ser Hasta Bakıcı & 300 \\
\hline İbrahim Efendi & Hasta Bakıcı & 100 \\
\hline Sait Efendi & Hasta Bakıcı & 100 \\
\hline Kadir Efendi & Vekilharç Muavini & 100 \\
\hline Osman Efendi & Anbar Memuru & $100^{32}$ \\
\hline
\end{tabular}

Bu kadar az kişi ile Zincidere Şifa Yurdu'nun hakkıyla vazifesini yapamayacağını gören İsmail Hakkı Bey, yurt için yeni kadro ve maaş taleplerini içeren bir liste hazırlamış ve tasdiki için 21 Eylül 1916 tarihinde Merkez-i Umumi'ye göndermiştir. Bu liste şu şekildedir ${ }^{33}$ :

\begin{tabular}{|l|l|r|}
\hline \multicolumn{1}{|c|}{ İsim } & \multicolumn{1}{c|}{ Görevi } & Maaş - (Kuruş) \\
\hline İsmail Hakkı Bey & Sertabib & 4.000 \\
\hline Kenan Bey & İdare Memuru & Merkezden alıyor \\
\hline Mustafa Bey & Doktor & 1.500 \\
\hline Ziya Efendi & Eczacı & Merkezden alıyor \\
\hline Hafız Kadri Efendi & Kâtip & 600 \\
\hline Sadık Efendi & Anbar Memuru & 100 \\
\hline Kadir Efendi & Vekilharç Muavini & 300 \\
\hline Sait Efendi & Kilerci Muavini & 300 \\
\hline İsmail Efendi & İnzibat Zabiti & 300 \\
\hline Hasibe Hanım & Ser Hastabakıcı & 100 \\
\hline İbrahim Efendi & Hastabakıcı & 100 \\
\hline Sait Efendi & Hastabakıcı & 100 \\
\hline Osman Efendi & Anbar Memuru & 100 \\
\hline Yani Efendi & Nezafet Memuru & \\
\hline
\end{tabular}

İsmail Hakkı Bey bu listeyi hazırlayıp Hilâl-i Ahmer Riyaseti'ne gönderdikten sonra özellikle doktor ihtiyacı için aynı gün yeni bir yazı daha göndermişti. Bu yazıya göre Zincidere Nekahethanesi, aralarında beş dakika mesafe olan ve 500 kişilik iki binada hizmet görmektedir. Yani Nekahethanenin 1.000 hasta ve nekahet mevcudu bulunmaktadır. İsmail Hakkı Bey'e göre bu iki binadan birisinin sıtma ve frengililere, diğerinin de cilt hastalıkları ve efrenciyye mütehassıs olmak üzere en

32 KA, 315/ 58, lef:2

33 KA, 315/ 58 lef: 2. 
az altı doktora ihtiyaç olduğu halde burada Mustafa Efendiden başka bir doktor bulunmamaktadır. Bu nedenle İsmail Hakkı Bey, bir doktorun yeterli olamayacağından her bina için hiç olmazsa ikişer doktor olmak ve birinin cilt hastalıkları ve efrenciyye mütehassıs ve bakteriyolog ve bir diğerinin de mümkünse dış hastalıklara mütehassısı olmak üzere en az üç doktorun daha tayin edilerek gönderilmesini istemiştir ${ }^{34}$.

İsmail Hakkı Bey, bu talebinin merkez tarafından karşılanmayacağını ön görmüş olsa gerek, bu yazısından yaklaşık bir hafta sonra Hilâl-i Ahmer Riyaseti'ne bir yazı daha göndererek, bu kez Talas Şifa Yurdu'nun da doktor ihtiyacına değinerek, her iki hastanede de görev yapmak üzere Kayseri'ye 2 doktor gönderilmesi talebinde bulunulmuştur ${ }^{35}$. Ancak bu talep de hemen karşılanamamıştır.

Bunun üzerine III. Ordu Sıhhîye Reisi Tevfik Salim Bey, Zincidere Nekahethanesi'nin mevcudunun eskiden olduğu gibi 500 yataklık bir nekahethane haline koyulmasını ve 250 yatağın yaralılara 250 yatağın da cerrahiye tahsisini uygun görmüştü. Tevfik Salim Bey, ayrıca nekahethanede biri bakteriyolog diğeri operatör olmak üzere iyi doktorlardan olan Osman ve Hayri Beyleri vazifelendirebilecekti. Ayrıca bu iki doktor, Zincidere'deki vazifelerinin dışında Talas Şifa Yurdu'ndaki hastalara da bakabilecekti ${ }^{36}$. III. Ordunun da araya girmesi ile Kasım ayı başlarında Yüzbaşı Osman Bey ve Operatör Hayri Bey, 1.000 kuruş maaşla görev yapmak üzere Kayseri'ye tayin edilmişlerdir ${ }^{37}$. Bunun dışında III. Ordu Riyaseti Nekahethanede bir ameliyathanenin kurulmasını da istemiştir. İsmail Hakkı Bey de Hilâl-i Ahmer Merkez-i Umumisinden ameliyathane için gerekli malzemeleri talep etmişti ${ }^{38}$.

Zincidere Hilâl-i Ahmer Nekahethanesi, kuruluşunu tamamlamaya çalışırken bir taraftan da faaliyetlerini yürütmekteydi. Savaş dolayısıyla o bölgede bulunan muhacirlerin arasında çok sayıda asker şehit aileleri ve öksüzleriyle kimsesiz kadınlar bulunmaktaydı. Kayseri Mutasarrıfı Zekai Bey, Kayseri ve civarında bulunan bu gibi kişilerin Zincidere

\footnotetext{
${ }^{34} \mathrm{KA}, 315 / 55$.

$35 \mathrm{KA}, 315 / 62$.

${ }^{36} \mathrm{KA}, 714 / 78$.

${ }^{37} \mathrm{KA}, 315 / 87$.

${ }^{38} \mathrm{KA}, 315 / 112$.
}

\section{(V) Vakaniivis}


Nekahethanesinde himaye altına alınarak iaşelerinin ve elbise ihtiyaçlarının giderilmesi ile tedavilerinin yapılmasını 12 Eylül 1916 tarihinde Dahiliye Nezareti'ne gönderdiği bir yazıda talep etmişti ${ }^{39}$. Dâhiliye Nezareti ise bu talebi uygun görmüş ve gereğinin yapılmasını Hilâl-i Ahmer Cemiyeti Merkezinden istemiştir ${ }^{40}$.

Görüldüğü üzere 1916 yılı Mayıs ayında Zincidere'ye taşınan Hilâl-i Ahmer Nekahethanesi kuruluşunu tam olarak ancak 1916 yılı sonlarında tamamlayabilmiştir. Ancak kurum bu süreçte faaliyetlerini de yürütmeye çalışmıştır.

\section{Zincidere Hilâl-i Ahmer Şifa Yurdunun 1917 ve yılındaki Faaliyetleri}

1917 yılı başlarında Hilâl-i Ahmer Kayseri Zincidere Nekahethanesi, dört binada faaliyet göstermeye başlamış ve kapasitesini ise 2.000 yatağa çıkarmıştır. Bu durumun nedeni Kayseri'nin bulunduğu konum ve Kafkasya Cephesi'ne olan yakınlığıydı. Ancak bu kadar hastaya ancak 3 doktor bakmaktaydı. Bunun dışında idare heyeti ise neredeyse yok idi. İdare memuru Kenan Bey, yaptığı işlerinin dışında, muhasiplik, kâtiplik, mubayaa işleri ve hatta karantina işlerine de bakmaktaydı. Ancak Kenan Bey, yatak mevcudu 2.000'e çıkınca artık bu işlere yetişemez olmuştu. Kayseri civarındaki bazı kaza, nahiye ve köylerde nekahethanenin ambarları bulunmaktadır. Oralardan tedarik edilen zahireler, çok ciddi zorluklarla merkeze nakledilmekte ve nekahethane kendi imkânlarıyla değirmenlerde kendisi öğütmektedir. Ekmeği kendi fırınlarında kendileri pişirmektedir. Nekahethane idaresi, bu işler için çeşitli adamlar kullanmaktaydı. Bu alt düzey memurlara yüzer kuruş gibi küçük maaşlar verilerek bu işler yaptırılmaktaydı. Büyük işlerin emanet edildiği bu kişilere pek de güvenilememektedir. Bu nedenle sertabip de merkezdeki işlerini bırakarak zaman zaman köylere bu işleri takip etmek için gitmektedir.

Sertabip İsmail Hakkı Bey, 22 Ocak 1917 tarihinde Hilâl-i Ahmer Riyaseti'ne bir yazı göndererek, nekahethanenin yukarıda zikredilen durumunu ifade ettikten sonra sıhhî işleri için 8 doktora ihtiyaç olduğunu belirtmiştir. İsmail Hakkı Bey, bunun dışında idari işler için en

\footnotetext{
${ }^{39}$ BOA, DH.i.UM.EK. 20/ 18, lef: 2.

${ }^{40}$ BOA, DH.I.UM.EK. 20/ 18, lef: 1.
}

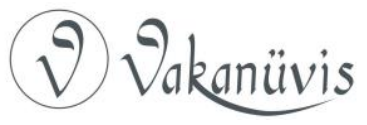


azından biri başkâtip olmak üzere hesap ve yazı işlerine vakıf iki kâtip; köylerde mubayaa işleriyle ilgilenecek iki mubayaa memuru; yazı işlerine vakıf bir karantina memuru talep etmiş ve nekahethanede müstahdem olarak kullanılmak üzere 50-60 kişinin vazifelendirilmesini istemiştir $^{41}$.

İsmail Hakkı Bey, Zincidere Nekahethanesi çalışanlarına diğer yerlerdeki doktor ve memurlara verildiği gibi erzak verilememekte olduğunu tespit etmişti. Bu durum, çalışanların şevk ve gayretlerini azaltmaktaydı. İsmail Hakkı Bey, 24 Ocak 1917 tarihinde Hilâl-i Ahmer Katib-i Umûmiliği'ne bir yazı göndererek Zincidere Nekahethanesinde kendisinden başka üç tabip olduğunu ve bunlara diğer yerlerdeki muadillerine verildiği gibi erzak verilmesini istemiştir ${ }^{42}$.

Hilâl-i Ahmer Kayseri Zincidere Nekahethanesi, zaman zaman paraya ihtiyaç duymaktaydı. Nitekim İsmail Hakkı Bey, 20 Şubat 1917 tarihinde merkezden acilen 2.000 liralık havale verilmesini istemiştir ${ }^{43}$. Hilâl-i Ahmer müesseslerinin bir diğer gelir kaynağı ise müzeyyenat (süs) eşyalarının satışlarından elde edilen gelirlerdi. Zincidere Nekahethanesi de bu satışları yapmaktaydı. Bu nedenle Nehakhane Müdürü Kanan Bey, 23 Şubat tarihinde Hilâl-i Ahmer Riyaseti'ne bir telgraf göndererek ${ }^{44}$, farklı renklerde iğne, billur kâğıt baskı, üç hükümdar levhası, köşeli baskı, kalın zincirli bilezik, cüzdan, yüzük sigara tabakası, sigara ağızlığı gibi yaklaşık 500 parça eşya ile birlikte 500 mektup defteri ve 2000 kartpostal talep etmiştir ${ }^{45}$. Bu kadar müzeyyanat eşyasının satışından ciddi miktarda gelirler elde edileceği düşünülmüştü.

Bu arada Zincidere Hilâl-i Ahmer Nekahethanesi adına önemli bir gelişme yaşanmıştı. Sertabip İsmail Hakkı Bey'in 15 Mart 1917 tarihinde Hilâl-i Ahmer Sivas Hastahanesi Sertababeti'ne gönderdiği bir yazıda nekahethanenin isminin Hilâl-i Ahmer Merkezi tarafından "Zincidere Hilâl-i Ahmer Şifa Yurdu" olarak değiştirildiği anlaşılmaktadır. Yine bu belgeye göre Zincidere Nekahethanesinin

\footnotetext{
${ }^{41} \mathrm{KA}, 315 / 134$.

$42 \mathrm{KA}, 315 / 138$.

${ }^{43} \mathrm{KA}, 315 / 149$.

${ }^{44} \mathrm{KA}, 315 / 151$.

${ }^{45} \mathrm{KA}, 315 /$ 151, lef: 1.
}

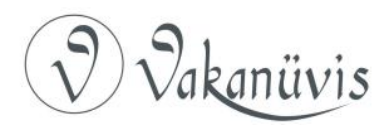


kapasitesinin 2.000 yatağa kadar çıkarıldığından bahsedilmişti. Bu yatakların yüz tanesi normal hastalıklara, iki yüz ellisi sıtma, iki yüz ellisi cerrahi, bin yatağı ise nekha taburu olarak askeriyeye ayrılmıştır ${ }^{46}$.

Artan bu kontenjan, personel ihtiyacını da artırmıştır. Bu amaçla göç döneminde Kayseri'ye gelmiş ve kimsesiz kalmış 40 kadar Ermeni kadın, gerekli eğitimleri aldıktan sonra personel ihtiyacını karşılamak için hasta bakıcı olarak vazifelendirilmişlerdir ${ }^{47}$.

Kayseri Zincidere Hilâl-i Ahmer Şifa Yurdu'nun Sertabibi İsmail Hakkı Bey'in yerine 19 Haziran 1917 tarihinde Cerrahpaşa Hastahanesi etıbbasından Mehmed Emin Bey tayin olmuştur ${ }^{48}$. Böylece İsmail Hakkı Bey'in yaklaşık 9 ay kadar yürüttüğü vazife sona ermişti.

Kayseri Zincidere Hilâl-i Ahmer Şifa Yurdu'nun personel sorunu Mehmet Emin Bey'in sertababetlik döneminde de devam etmişti. Bu dönemde Şifa Yurdunda 20 hastabakıcı hemşire mevcut olup bunlar vaktiyle hükumet marifetiyle alınmış olduklarından maaşsız olarak vazifelerini yerine getirmekteydiler. Ancak ordu hastanelerine maaşı yüksek kadın hasta bakıcı alınması, Şifa Yurdundaki hemşirelerin de peyderpey oraya kaymalarına neden oldu. Bu durumun yurdun sıhhî işlerini felç edeceğini gören Mehmet Emin Bey, Hilâl-i Ahmer Riyaseti'nden Ağustos ayından itibaren her birine aylık bir lira maaş tahsis edilmesini istemiştir ${ }^{49}$.

Personel ihtiyacı sorunlarıyla uğraşan Zincidere Nekahethanesi, bölge halkının sıhhî ihtiyaçlarının yanında Eylül 1917 ayı içerisinde bir Darülaceze'nin açarak burada ihtiyaç sahiplerine günlük olarak yemek dağıtılmasını sağlamıştır ${ }^{50}$. Müessese bunun dışında halkın bireysel ihtiyaçları ile de yakından ilgilenmiştir. Şifa Yurdu tarafından bakımları sağlanmakta olan Bosnalı bir muhacir ailenin sağ ayağı kangren

\footnotetext{
${ }^{46} \mathrm{KA}, 325 / 328$.

${ }^{47}$ Seçil Karal Akgün, Murat Uluğtekin, Yeni Belgeler Işığında Hilâl-i Ahmer'den Kızılay'a, Türk Kızılayı Derneği Yayınları, Ankara 2020, s. 306.

$48 \mathrm{KA}, 588 / 8$.

$49 \mathrm{KA}, 315 / 156$.

$50 \mathrm{KA}, 315 / 159$.
}

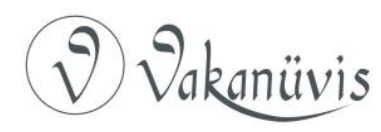


sebebiyle kesilen kızları için bir protez bacak istenmiştir ${ }^{51}$. Bu suretle bir Hilâl-i Ahmer müessesesi şefkat yüzünü göstermekteydi.

Zincidere Hilâl-i Ahmer Şifa Yurdu için gerekli ekmeklik unun devletin belirlediği fiyat ile askeriyeden alınması kararlaştırılmıştı. Ayrıca hastanenin iaşesinde kullanılmak üzere bölgede bir bağ tedarik edilmişti ${ }^{52}$. Bu gibi tedbirlerin dışında Zincidere Şifa Yurdu kışlık ihtiyacı için Kasım 1917 ayı içerisinde Kırşehir'den eşya satın alınması kararlaştırılmıştı ${ }^{53}$.

Kayseri Zincidere Hilâl-i Ahmer Şifa Yurdu'nun diğer bir faaliyeti ise savaş ortamlarında sayıları bir hayli artan kimsesiz çocuklar üzerindeydi. Özellikle Türk ordusu geri çekilirken Ruslar tarafından işgal edilen topraklarda çok sayıda insan evsiz kalmış durumdaydı. Bu insanlar arasında azımsanamayacak sayıda yetim kimsesiz çocuk da bulunmaktaydı. Bölgedeki sağıık kuruluşları da kimsesiz çocuklara sahip çıkmaktaydı. Ordunun emri üzerine Zincidere Şifa Yurdu da yaklaşık 500 yetim çocuk kabul etmiş ve bunları muhafazası altına almıştır. Bu çocuklar son derece bakımsız ve çıplak denecek bir vaziyette hastaneye kabul olmuşlardır. Hilâl-i Ahmer tarafından kimsesiz çocukların her birine üç kat çamaşır, çorap ve fanila tedarik edilmiştir ${ }^{54}$.

Şifa Yurdu'na gelen bu kimsesiz 500 çocuğun bakımı, kurumun personel ihtiyacını daha belirgin bir hale getirmiştir. Şifa Yurdu Sertabibi Mehmet Emin Bey, 500 çocuğa nezaret etmek üzere 13 Kasım 1917 tarihinden itibaren aylık 200 kuruş maaşla bir hemşire vazifelendirmiştir ${ }^{55}$. Bu arada Şifa Yurdu görevlileri, bu çocukların tüm ihtiyaçlarıyla ilgilenmenin yanı sıra bu çocuklara yaşlarına göre çeşitli görevler vererek onların bir zanaat kazanmasını sağlamaya çalışmışlardır ${ }^{56}$.

Zincidere Hilâl-i Ahmer Şifa Yurdunun 1917 yılı Mart-Nisan ayından itibaren faaliyetlerin çok fazla olmadığı görülmektedir. Bunun en

\footnotetext{
${ }^{51} \mathrm{KA}, 315 / 161$.

$52 \mathrm{KA}, 714 / 52$.

$53 \mathrm{KA}, 315 / 158$.

${ }^{54}$ Murat Uluğtekin Gül Uluğtekin, İcraat Raporları, s. 14.

$55 \mathrm{KA}, 315 / 160$.

${ }^{56}$ Çapa, Kızılay (Hilâl-i Ahmer) Cemiyeti, s. 82.
}

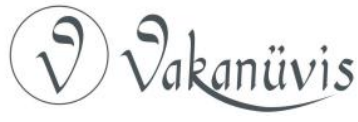


önemli nedeni Mart 1917 tarihinde Rusya'da ihtilalin olması ve Rusya ile Osmanlı Devleti arasında gayr-i resmi bir mütareke durumunun ortaya çıkmasıydı. Bu durum, Mart 1917'den Şubat 1918 tarihine kadar devam edecektir.

\section{Zincidere Hilâl-i Ahmer Şifa Yurdunun 1918 Yılındaki Faaliyetleri}

Zincidere Hilâl-i Ahmer Şifa Yurdu'nun 1918 yılı faaliyetlerine geçmeden yurdun personel durumu ile alakalı bilgiler vermek yerinde olacaktır. Nitekim Kızılay Arşivi'nden edinilen bir belgeden Şubat 1918 ayına ait Şifa Yurdunun personel mevcudu ile alakalı detaylı bilgilere ulaşmaktayız. Buna göre Şifa Yurdunun yönetici kadrosu şu şekildedir:

\begin{tabular}{|l|r|}
\hline \multicolumn{2}{|c|}{ Kayseri Zincidere Hilâl-i Ahmer Şifa Yurdu (Görevliler) } \\
\hline Görev & Adeti \\
\hline Sertabib Mükellef & 1 \\
\hline Tabib Mükellef Yüzbaşı & 1 \\
\hline Eczacı Mükellef Mülazım & 1 \\
\hline İnzibat Zabiti Mülazımı Sani & 1 \\
\hline Mübayaa ve Nakliyat Memuru & 1 \\
\hline Anbar Memuru Mükellef & 1 \\
\hline Karantina Memuru Nefer & 2 \\
\hline
\end{tabular}

Zincidere Hilâl-i Ahmer Şifa Yurdu'nun yönetici olarak nitelendirebileceğimiz bu kadrosunda 8 personel görev yapmaktadır. Şifa Yurdu'nun diğer personelleri ise şu şekildedir:

\begin{tabular}{|l|r|}
\hline \multicolumn{2}{|c|}{ Kayseri Zincidere Hilâl-i Ahmer Şifa Yurdu (Diğer Görevliler) } \\
\hline Görev & Adeti \\
\hline Çamaşırcı Kadın & 10 \\
\hline Berber(Ücretsiz) & 2 \\
\hline Nezafet Memuru & 1 \\
\hline Terzi Kadın & 5 \\
\hline Ser Hastabakıcı Kadın & 2 \\
\hline Aş̧ı & 5 \\
\hline Çamaşırcı & 2 \\
\hline Bahçıvan & 2 \\
\hline
\end{tabular}




\begin{tabular}{|l|r|}
\hline Marangoz & 4 \\
\hline Camcı & 2 \\
\hline Şehadetnamesiz Sıhhîye Efradı & 10 \\
\hline Şubata Mütehassis Yanında Nefer & 1 \\
\hline Şehadetnameli Hastabakıcı Efrad & 4 \\
\hline Gayri Müsellah Efrad & 67 \\
\hline Hırdabil & 1 \\
\hline Etüv Memuru & 1 \\
\hline
\end{tabular}

$\mathrm{Bu}$ görevlilerin yanı sıra Şifa Yurdunda küçük zabit olarak nitelendirilen 10 başçavuş, 5 onbaşı ve 3 narhçı nefer görev yapmaktadır. Bunun dışında Şifa Yurdu'na ait vesait ve hayvanların listesi şu şekildedir:

\begin{tabular}{|l|r|}
\hline \multicolumn{2}{|c|}{$\begin{array}{c}\text { Kayseri Zincidere Hilâl-i Ahmer Şifa Yurdu (Nakliye Vesaiti ve } \\
\text { Hayvanat) }\end{array}$} \\
\hline Görev & Adeti \\
\hline Yaylı Araba & 9 \\
\hline Forgut & 9 \\
\hline Kağnı & 8 \\
\hline Koşum Hayvanatı & 1 \\
\hline Ester(Katır) & 16 \\
\hline Öküz & 13 \\
\hline Merkep & 79 \\
\hline Sütsüz İnek & 50 \\
\hline Sütsüz Koyun & $38^{57}$ \\
\hline Sütsüz Keçi & \\
\hline
\end{tabular}

Zincidere Hilâl-i Ahmer Şifa Yurduna ait yukarıdaki bilgileri edindiğimiz Kızılay Arşivi Belgesine göre 8 yönetici kadrosunda 137 diğer görevlerde olmak üzere 145 personel çalışmaktadır. Bunun dışında 19 nakliye aracı ve 197 hayvan mevcudu bulunmaktadır.

Şubat 1918 'de Zincidere Hilâl-i Ahmer Şifa Yurdunda 595 hasta ve 59 yaralı toplamda 654 asker bulunmaktaydı. Şubat ayı içinde salgın hastalık sonucu 2 asker vefat etmiştir. 84 asker ise salgına karşı

57 KA, 867/ 78.

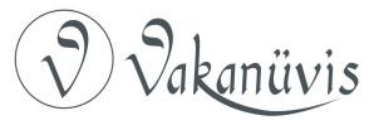


tedavileri tamamlanarak iyileşmiştir ${ }^{58}$. Yine 20 Şubat 1918 verilerine göre Şifa Yurdu'nda 576 hasta ve 59 yaralı bulunmaktaydı ${ }^{59}$.

Zincidere Şifa Yurdu'nda Mart 1918'de toplam 511 hasta ve 52 yaralı toplam 563 asker bulunmaktadır. Mart sonu itibariyle hasta sayısı 526 ve yaralı sayısı 35 olup toplam tedavi gören asker sayısı 561 olmuştur. Mart ayı itibariyle 3 asker salgın sebebiyle vefat etmiştir ${ }^{60}$. Ayrıca tedavi gören bir asker ve bir memur sarı hastalığının etkisiyle "sillirrie (akciğer veremi)" hastalığına yakalanmıştır. Bunun dışında bir asker ve bir memur da yine sarı hastalığı etkisiyle "zatürreye" hastalığına yakalanmıştır ${ }^{61}$.

Mayıs 1918 'de ise Zincidere Şifa Yurdu'nda toplamda 411 hasta ve 51 yaralı bulunmaktaydı ${ }^{62}$. Yine bu ay içerisinde yurtta tedavi edilen askerlerde, 1 iskorbüt hastalığı, 15 donma, 5 sarı veremi, 1 frengi, 6 fıtık, 2 kemik kırılması, 34 yaralı ve 49 sarı hastalığı görülmüştür. Sarı hastalığına yakalanan 49 kişiden ikisi yurtta bakılan kimsesiz çocuklardandır63.

Zincidere Hilâl-i Ahmer Şifa Yurdu, 1918 yılı içerisinde de kimsesiz çocukların bakımını sağlamaya devam etmekteydi. Şifa Yurdu'nda bulunan kimsesiz çocukların şubat 1918 tarihinde durumu şu şekildedir:

\begin{tabular}{|c|c|c|c|c|c|c|}
\hline Hastane & 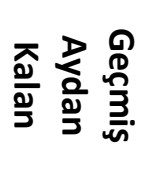 & $\begin{array}{l}\text { ס } \\
\text { 皇 } \\
\text { 玉 }\end{array}$ & 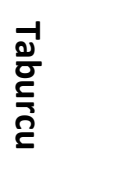 & z & $\underset{\substack{d \\
\stackrel{d}{d}}}{\stackrel{\delta}{d}}$ & 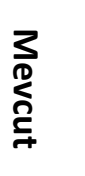 \\
\hline $\begin{array}{l}\text { Zincidere Hilâl- } \\
\text { i Ahmer Şifa } \\
\text { Yurdu Eytam } \\
\text { Etfal-i } \\
\text { Metruke }\end{array}$ & 387 & 145 & 24 & 32 & - & 476 \\
\hline
\end{tabular}

\footnotetext{
$58 \mathrm{KA}, 867 / 84$.

${ }^{59} \mathrm{KA}, 867 / 81$.

$60 \mathrm{KA}, 867 / 86$.

$61 \mathrm{KA}, 867 / 113$.

$62 \mathrm{KA}, 315 / 191$, lef:1.

63 KA, 315/ 191, lef:2.
} 


\begin{tabular}{|l|r|r|r|r|r|r|}
\hline Mevcudu & & & & & & \\
\hline $\begin{array}{l}\text { Etfali } \\
\text { Metrukeden } \\
\text { Hasta } \\
\text { Mevcudu }\end{array}$ & 9 & 32 & 5 & - & 5 & 31 \\
\hline Yekûn & & & & & & \\
\hline
\end{tabular}

Bu belgeye göre Zincidere Hilâl-i Ahmer Şifa Yurdu bünyesinde Ocak 1918 'de 387 yetim çocuğun bulunduğu görülmektedir. Şubat ayında ise 145 çocuk daha şifa yurdunda himaye altına alınmış ve iyileşerek taburcu edilen 24 çocuk, anneleri tarafından alınmıştır ${ }^{64}$. Buna göre şifa yurdu bünyesinde Şubat ayı sonu itibariyle 507 kimsesiz çocuk Zincidere Hilâl-i Ahmer Şifa Yurdu bünyesinde barındırılmaktadır.

Sayı olarak Şubat ayında 507'ye kadar ulaşan bu çocukların sayısı sadece birkaç ayda ciddi bir oranda azalma göstermiştir. Mart ayında bu sayı 47865, Nisan ayında 296 ve Mayıs ayında 270'e kadar düşecektir ${ }^{66}$. Bu şekilde Şifa Yurdu'nda bulunan çocukların sayıları sadece birkaç ay içinde yarı yarıya düşmüştür.

Zincidere Hilâl-i Ahmer Şifa Yurdu, çoğunlukla 2.000 yatağa kadar çıkan kapasitesinin tamamını kullanmaktaydı. Mevcudun bu kadar çok olması yiyecek ihtiyaçlarının karşılamasında sorunlar yaşamasına neden olmuştur. Şifa Yurdu idarecileri bu sorunları aşmak için özellikle cemiyet merkezine farklı zamanlarda hem nakdi hem de erzak talebinde bulunmuştur. Bu amaçla Zincidere Hilâl-i Ahmer Şifa Yurdu

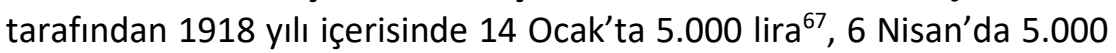
lira ${ }^{68}, 24$ Mayıs'ta 5.000 lira $^{69}, 21$ Haziran'da 5.000 lira $^{70}, 22$ Ağustos'ta 5.000 lira talebinde bulunulmuştur ${ }^{71}$.

\footnotetext{
${ }^{64} \mathrm{KA}, 867 / 80$.

${ }^{65} \mathrm{KA}, 867 / 113$, lef:2.

${ }^{66} \mathrm{KA}, 315 / 195$.

$67 \mathrm{KA}, 315 / 166$.

$68 \mathrm{KA}, 315 / 184$.

${ }^{69} \mathrm{KA}, 315 / 196$.
}

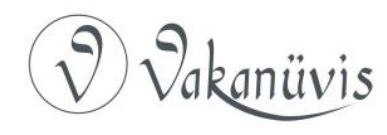


Zincidere Şifa Yurdu İdaresi, yurtta kalan hastaların günlük kalori ihtiyacını titizlikle karşılamaya çalışmaktaydı. Bu durum Kızılay Arşivi'nden elde edilen bir belgeye de yansımıştır. Bu belgeye göre Zincidere Hilâl-i Ahmer Şifa Yurdu'ndaki hastalara günlük olarak verilen yemek ve kalori miktarı şu şekildedir ${ }^{72}$ :

\begin{tabular}{|l|l|l|l|}
\hline Erzakın Cinsi & $\begin{array}{c}\text { Günlük olarak } \\
\text { verilen miktar } \\
\text { (gram) }\end{array}$ & $\begin{array}{c}\text { Ortaya Çıkan } \\
\text { Kalori (adedi) }\end{array}$ & $\begin{array}{c}\text { Muhtevi } \\
\text { Olduğu } \\
\text { Elyevm } \\
\text { Miktarı(gram) }\end{array}$ \\
\hline $\begin{array}{l}\text { Buğday Unu } \\
\text { (ekmek) }\end{array}$ & 300 & 1071 & 30,63 \\
\hline $\begin{array}{l}\text { Çavdar Unu } \\
\text { (ekmek) }\end{array}$ & 300 & 1056 & 34,71 \\
\hline Et & 300 & 303 & 61,87 \\
\hline Yağ & 15 & 118 & 11 \\
\hline Çorbalık Un & 10 & 35 & 1 \\
\hline Bulgur & 30 & 105 & 2,5 \\
\hline Kuru Sebze & 125 & 358 & 23 \\
\hline Yekûn & - & 3.043 & 153,82 \\
\hline
\end{tabular}

Buna tabloya göre Zincidere Hilâl-i Ahmer Şifa Yurdunda tedavi görenler için günlük olarak çorba, et, bulgur ve sırasıyla fasulye, mercimek ve patates gibi yiyecekler verilmektedir. Ayrıca yapılan hesap içinde kalori miktarlarının da kayıtlara geçirilmesi kurumda her işin hesaplı bir şekilde yapıldığını gösterir niteliktedir.

Günlük olarak bu ihtiyacı karşılayan kurumun erzak miktarını da sürekli olarak dolu tutması gerektiği anlaşılmaktadır. Bu amaçla sık sık erzak takviyesi alınarak ihtiyaçlar karşılanmaya çalışımıştır. Şifa Yurdunun Eylül 1918 erzak durumu şu şekildedir ${ }^{73}$ :

\begin{tabular}{|l|r|r|}
\hline Eşya & Kilo & \multicolumn{2}{|c|}{ Gram } \\
\hline Bulgur & 2.503 & 160 \\
\hline Yağ & 1.559 & 165 \\
\hline
\end{tabular}

\footnotetext{
70 KA, 315/ 202.

$71 \mathrm{KA}, 315 / 210$.

$72 \mathrm{KA}, 867 / 2$.

$73 \mathrm{KA}, 315 / 212$.
} 


\begin{tabular}{|l|r|r|}
\hline Un & 63.999 & 670 \\
\hline Burçak & 2.178 & 00 \\
\hline Tuz & 3.772 & 235 \\
\hline $\begin{array}{l}\text { Mahlute (Çavdar ve } \\
\text { Buğday) }\end{array}$ & 1.971 & 00 \\
\hline Buğday & 12.187 & 00 \\
\hline $\begin{array}{l}\text { Bulgura katılmış } \\
\text { Buğday }\end{array}$ & 4.044 & 500 \\
\hline Şeker & & \\
\hline Zeytinyağı & 187 & 370 \\
\hline Soda & 81 & 645 \\
\hline Sabun & 151 & 300 \\
\hline Nohut & 232 & 455 \\
\hline Fasulye & 1.307 & 750 \\
\hline Mercimek & 1.652 & 625 \\
\hline Kuru Bamya & 1485 & 880 \\
\hline Bakla & 165 & 990 \\
\hline Çavdar & 90 & 200 \\
\hline Arpa & 4428 & 500 \\
\hline Saman & 20447 & 500 \\
\hline Kaymak & 6514 & 00 \\
\hline
\end{tabular}

Kayseri Zincidere Şifa Yurdu'nun bu şekilde I. Dünya Savaşı boyunca ordunun hasta ve yaralı askerlerini tedavileri için çaba harcadığını görmekteyiz. Bunun dışında Şifa Yurdu, bölgedeki mülteci ve kimsesiz çocukları himayesi altına almıştır. Kısıtlı imkân ve personel kadrosuyla bu önemli yükü omuzlayan Zincidere Hilâl-i Ahmer Şifa Yurdu, görevini eksiksiz olarak yerine getirmeye çalıştığı görülmektedir.

\section{Zincidere Hilâl-i Ahmer Şifa Yurdunun Kapatılması}

Birinci Dünya Savaşı́nın sona ermesiyle birlikte Hilâl-i Ahmer Cemiyeti, savaş bölgelerinde açtığı bazı hastaneleri kapatma kararı almıştır. Bu kararın alınmasında ki temel etken savaşın bitmesi dolayısıyla bu kurumlara intiyaç olmayacağı düşüncesiydi. Bu amaçla kararın alındığı yerlerden biriside Kafkas Cephesine hizmet etmek amacıyla açılan Zincidere Hilâl-i Ahmer Şifa Yurdu'dur. Özellikle Talas Şifa Yurdu'nun da bölgede bulunması ve bu hastanenin bölge için

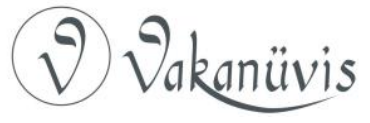


zaruri olmaması savaş bitiminde kapatılması kararı alınmasında etkendir. Bu sebepler, Eylül 1918 sonlarında şifa yurdunun kapatılma kararının alınmasına neden olmuştur. Kurumun kapatılma kararı

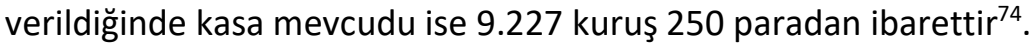

Kapatılma kararı sonrasında Sertabib Operatör Mehmet Emin Bey, 22 Eylül 1918 tarihinde Hilâl-i Ahmer Riyaseti'ne müracaat ederek, kış hazırlıklarının yapıldığı için erzak depolarının dolu olduğunu merkeze bildirmişti. Bunun dışında kurumda görevli olan memurların durumunun ne olacağını da merkeze sormaktayd $\imath^{75}$.

Zincidere Hilâl-i Ahmer Şifa Yurdu'nun kapatılma sürecinde yurtta kalan malzeme ve eşya listesi şu şekildedir ${ }^{76}$ :

\begin{tabular}{|l|r|l|r|}
\hline Eşya & \multicolumn{1}{|c|}{ Adeti } & Eşya & Adeti \\
\hline Yatak Kılıfı & 1235 & Yastık Yüzü & 601 \\
\hline Yorgan & 1805 & Astarlı Uçkur & 34 \\
\hline Yastık Kılıfı & 1998 & Ufak Bohça & 33 \\
\hline Yorgan Kılıfı & 2117 & Hırka & 586 \\
\hline Yatak Çarşafı & 2552 & Masa Örtüsü & 110 \\
\hline Don & 1257 & Ruba & 220 \\
\hline Gömlek & 1345 & Entari & 23 \\
\hline Fanila & 516 & Takye & 935 \\
\hline Kaput & 324 & Yatak & 13 \\
\hline Çorap & 705 & Yastık & 9 \\
\hline Battaniye & 172 & Peştamal & 21 \\
\hline Havlu & 806 & Çadır & 5 \\
\hline
\end{tabular}

Tablodan da görüldüğü üzere Zincidere Şifa Yurdu'nda yaklaşık olarak 2.000 hastaya yetecek kadar eşya ve malzeme bulunmaktaydı. Bu süreçte kurumda bulunan hayvanların cinsi ve âdeti şu şekildedir ${ }^{77}$ :

\begin{tabular}{|c|c|c|c|}
\hline Hayvan & Adeti & Hayvan & Adeti \\
\hline Sığır & 232 & Kuzu & 15 \\
\hline Keçi & 54 & Dana & 10 \\
\hline
\end{tabular}

\footnotetext{
74 Uluğtekin ve G. Uluğtekin, Icraat Raporları, s.646.

$75 \mathrm{KA}, 315 / 232$.

$76 \mathrm{KA}, 315 / 212$.

77 KA, 315/ 215.
} 


\begin{tabular}{|l|r|l|r|}
\hline Koyun & 1099 & At & 4 \\
\hline Oğlak & 11 & Merkep & 11 \\
\hline
\end{tabular}

Zincidere Şifa Yurdu İdaresi, yukarıda görüldüğü üzere elindeki malzeme, eşya ve erzakın envanterini çıkarmaktaydı. Bu arada kurumda bulunan tıbbi araç ve gereçlerin tamamı Talas Şifa Yurdu'na devredilmiştir. Ayrıca bölgede bulunan bazı kurumların Şifa Yurdu'nun kapatılma sürecinde yurttan erzak ve malzeme alma niyetinde bulunduklarını görmekteyiz. Örneğin Zincidere'de bulunan Küçük Zabit Mektebi Müdürü İbrahim Bey, Şifa Yurduna ait erzak, kuru sebze, odun ve soba gibi malzemelerin bir kısmını kendi kurumlarına verilmesi için müracaata bulunmuştu ${ }^{78}$. Bu şekilde Zincidere Hilâl-i Ahmer Şifa Yurdu'nun malzeme, erzak ve tüm eşyalarının devri sağlanarak kapatılma işlemleri tamamlanmaya çalışılmıştır.

Zincidere Şifa Yurdu'nun kapatılmasıyla ilgili diğer önemli bir meselede kurumda görev yapanların durumlarının ne olacağı ile alakalıydı. Hilâl-i Ahmer Cemiyeti Merkezi, kurumdaki tüm memurların İstanbul'a getirilerek buradaki hastanelerde göreve başlayacaklarını Şifa Yurdu idarecilerine bildirilmiştir. Ancak bu kez de Sertabip Mehmet Emin Bey, 3 Ekim'de Hilâl-i Ahmer Cemiyeti Riyaseti'ne gönderdiği yazıda hemşirelik eğitimi verilerek Şifa Yurdu'nda çalıştırılan 20 kadar sahipsiz Ermeni kadının İstanbul'a getirilmelerinde her hangi bir sakınca olup olmadığını sormaktaydı ${ }^{79}$. Merkezden gelen cevap olumlu idi. Ermeni kadınlar, İstanbul'a getirilecekler ve diğer memurlar gibi orada bulunan hastanelerde göreve başlatılacaklardı ${ }^{80}$. Tabi burada Ermeni kadınların da isteği göz önünde tutulacaktı ${ }^{81}$.

Zincidere Şifa Yurdu'nun kapatılması sürecinde diğer bir mesele ise mevcut hasta ve kimsesiz çocukların durumu idi. Şifa Yurdunda bulunan mevcut hastalar, peyderpey Merkez Hastanesine nakledilmişlerdir ${ }^{82}$. Bunun dışında yurtta bulunan 200'den biraz fazla olan kimsesiz çocuklar, Talas Şifa Yurdu'na nakledilmişlerdir ${ }^{83}$. Bu

\footnotetext{
$78 \mathrm{KA}, 315 / 214$.

$79 \mathrm{KA}, 315 / 213$.

80 Osmanlı Hilâl-i Ahmer Mecmuası, (15 Teşrin-i Sani 1337-1921), Sayı:3, s. 63.

81 Murat Uluğtekin Gül Uluğtekin, Icraat Raporları, 14.

$82 \mathrm{KA}, 315 / 222$.

${ }^{83}$ Akgün ve Uluğtekin, Yeni Belgeler Işığında Hilâl-i Ahmer'den Kızılay'a, s. 307.
}

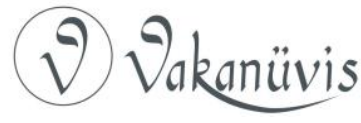


şekilde Şifa Yurdundaki hasta ve kimsesiz çocuklar diğer kurumlara gönderilirken, erzak ve malzeme sorunu hala devam etmekteydi. Nitekim 9 Aralık 1918 tarihinde hasta kimsenin kalmadığını cemiyetin merkezine bildiren Mehmet Emin Bey, külliyetli bir şekilde kalan eşya ve erzak hakkındaki gerekli talimatın bir an önce verilmesini istemiş ve "Ereğli'ye nakliyata başlayalım mı?" şeklinde soru yöneltmiştir ${ }^{84}$. Illerleyen günlerde erzakın ve malzemenin bir kısmı çevredeki kurumlara verilmiş, kalan kısmı ise satışa çıkarılmıştır ${ }^{85}$.

Yine kurumun kapatılma ve İstanbul'a gitme durumunun memurların ailelerini de ilgilendirmekte olduğunu görmekteyiz. İstanbul'a gidecek olan kafileye dahil olan memurların aileleri ile ilgili bilgilerde merkeze verilerek sivil yolcu sayısı belirlenmeye çalışılmaktadır ${ }^{86}$. Aralık ayı başına geldiğimizde ise Mehmet Emin Bey tüm hazırlıkların tamamlandığını, kurumun kapatılması ile ilgili tüm işlerin tamamlandığını belirterek 10 Aralık 1918 tarihinde, şifa yurdu doktorları, memurları ve aileleri ile 20 kadar Ermeni sahipsiz kadının Kayseri'den yola çıkarak İstanbul'a geleceğini bildirmiştir ${ }^{87}$.

Bu şekilde 1916 yılının sonlarında doğu bölgesindeki Rus işgalleri sebebiyle Kemah'tan Kayseri'ye taşınan ve savaşın devam ettiği dönemde yaklaşık 2 yıl faaliyette olan Zincidere Hilâl-i Ahmer Şifa Yurdu 1918 yılının sonlarında intiyaç kalmadığı düşüncesiyle kapatılmıştır. Şifa Yurdu'nun kapatılmasıyla birlikte Kayseri Hilâl-i Ahmer Cemiyeti'nin de faaliyetlerine bir süreliğine ara verildiği görülmektedir.

\section{Sonuç}

I. Dünya Savaşı'nın zor şartları altında görev yapmaya çalışan Hilâl-i Ahmer Cemiyeti, savaş için stratejik öneme sahip bölgelerde hastane, nekahethane, şifa yurdu gibi sıhhî kurumlarla faaliyet göstermiştir. Açılan bu kurumlar sayesinde ölümler azalmış, yaralılar ve hastalar daha erken iyileştirilmiş ve bulaşıcı hastalıkların yayılması önlenmeye çalışılımışır. Bu kurumlardan biriside Kayseri'de bulunan Zincidere

\footnotetext{
${ }^{84} \mathrm{KA}, 315 / 215$.

$85 \mathrm{KA}, 315 / 230$.

${ }^{86} \mathrm{KA}, 315 / 224$.

$87 \mathrm{KA}, 315 / 231$.
}

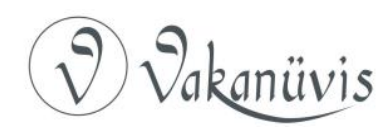


Nekahethanesi olmuştur. Kurum savaşın ilerleyen zamanlarında ordunun aldığı kararla nekahethane olarak başladığı görevine bir Şifa Yurdu olarak devam etmiştir.

Kafkas cephesinde önemli mücadeleler gösteren Türk kuvvetlerinin hasta ve yaralıları bölgeye nispeten yakın olan ve Kayseri'de bulunan Zincidere Hilâl-i Ahmer Şifa Yurdu'nda tedavi edilmişlerdir. III. Ordu komutasında olan kurum, Kafkas cephesinin tüm sıhhî faaliyetlerinin önemli bir merkezi olmuştur. İlk başlarda 500 yatak kapasitesi ile kurulan Zincidere Hilâl-i Ahmer Şifa Yurdu'nun ilerleyen zamanlarda kapasiteni 2.000 yatağa çıkarmıştır. Bu durum Dünya Savaşı için ne denli önemli bir görevi üstlendiğini göstermektedir.

Kayseri Zincidere'de Hilâl-i Ahmer Şifa Yurdu'nun diğer bir önemli faaliyeti ise savaşın sayılarını bir hayli artırdığı kimsesiz çocuklardı. Ordunun emri üzerine Zincidere Şifa Yurdu da yaklaşık 500 yetim çocuk kabul etmiş ve bunları muhafazası altına almıştır. Kurum kapanıncaya kadar bu çocukların muhafazası ile ilgilenmiştir. Şifa Yurdu'nun dâhil olduğu önemli bir vakıa ise kimsesiz kalan 40 kadar Ermeni kadının, gerekli eğitimleri aldıktan sonra personel ihtiyacını karşılamak için şifa yurdunda hastabakıcı olarak görevlendirilmeleridir. Bu kadınlara kurumun kapatılma kararı sonrasında, eğer isterlerse İstanbul'daki hastanelerde görev yapma imkânı verilmiştir.

Son olarak Kayseri Zincidere Hilâl-i Ahmer Şifa Yurdu, I. Dünya Savaşı süresince cephede ve cephe gerisinde önemli hizmetlerde bulunmuştur. Kurumun hizmetleri sadece askeri ve sıhhî anlamda kalmamış ve insani vazifeler de takdire şayan bir şekilde yerine getirilmiştir. Hilâl-i Ahmer Cemiyeti'nin diğer kurumları da aynı şekilde hizmet verdiği için halkın büyük teveccühünü kazandığı görülmektedir. Bu suretle Cemiyet, Osmanlı'dan Cumhuriyet'e geçiş sürecinde en büyük sivil toplum kuruluşu olma özelliğini kazanmıştır.

\section{Kaynakça}

Arşiv Kaynakları

Kızılay Arşivi (KA)

SALT Araştırma, Harika-Kemali Söylemezoğlu Arşivi

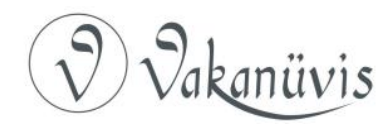


Türkiye Cumhuriyeti Cumhurbaşkanlığı Devlet Arşivleri Başkanlığı Osmanlı Arşivi (BOA)

\section{Süreli Yayınlar}

Osmanlı Hilâl-i Ahmer Mecmuası

\section{Raporlar ve Salnamaler}

Osmanlı Hilâl-i Ahmer Cemiyeti Salnamesi (1329-1331), Matbaa-i Ahmet İhsan ve Şürekâsı, İstanbul, (t.y).

Osmanlı'dan Cumhuriyet'e Hilâl-i Ahmer Icraat Raporları (1914-1928), Yay. Haz. Murat Uluğtekin, M. Gül Uluğtekin, Türk Kızılayı Yayınları, Ankara, 2013.

Türkiye Hilâl- i Ahmer Cemiyeti Merkez-i Umumisi Tarafından 1339 Senesi Hilâl- i Ahmer Meclis- i Umumisine Takdim Edilen (1335-1338) Dört Senelik Devreye Ait Rapor, Matbaa-i Ahmed ihsan ve Şürekâsı, İstanbul, 1339.

\section{Kitap, Makale ve Tezler}

Ada, Hüsnü, Osmanlı Devletinin Hizmetinde Illk Modern Osmanlı Sivil Toplum Örgütü: Osmanlı Hilâl-i Ahmer Cemiyeti (1868-1911), Basılmamış Doktora Tezi, Marmara Üniversitesi Türkiyat Araştırmaları Enstitüsü, İstanbul 2011.

Akgün, Seçil Karal- Uluğtekin, Murat, Yeni Belgeler Işığında Hilâl-i Ahmer'den Kızılay'a, Türk Kızılayı Derneği Yayınları, Ankara 2020.

Besim Ömer, Hanımefendilere Hilâl-i Ahmer'e Dair Konferans, Ahmet Ihsan ve Şürekâsı Matbaacılık Osmanlı Şirketi, İstanbul 1330.

Çapa, Mesut, Kızılay (Hilâl-i Ahmer) Cemiyeti, Türkiye Kızılay Derneği Yayınları, Ankara 2009.

Develioğlu, Ferit, Osmanlıca-Türkçe Ansiklopedik Lûgat, Aydın Kitabevi, 2013. 


\section{EKLER}

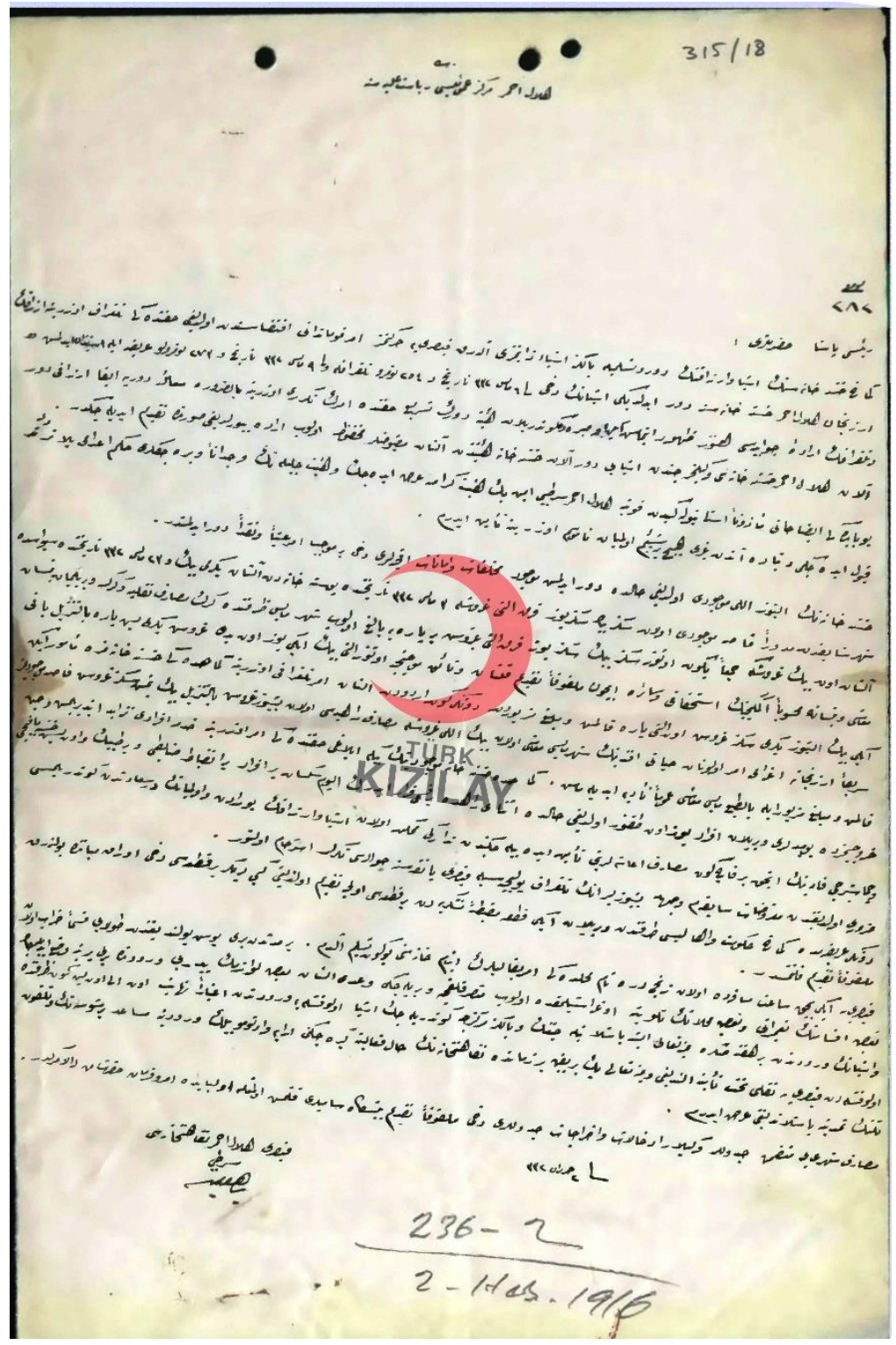

EK-1) Zincidere Hilal-i Ahmer Nekahethanesi'nin kuruluş sürecini anlatan Sertabip Burhaneddin Bey'in raporu (KA, 315/18) 


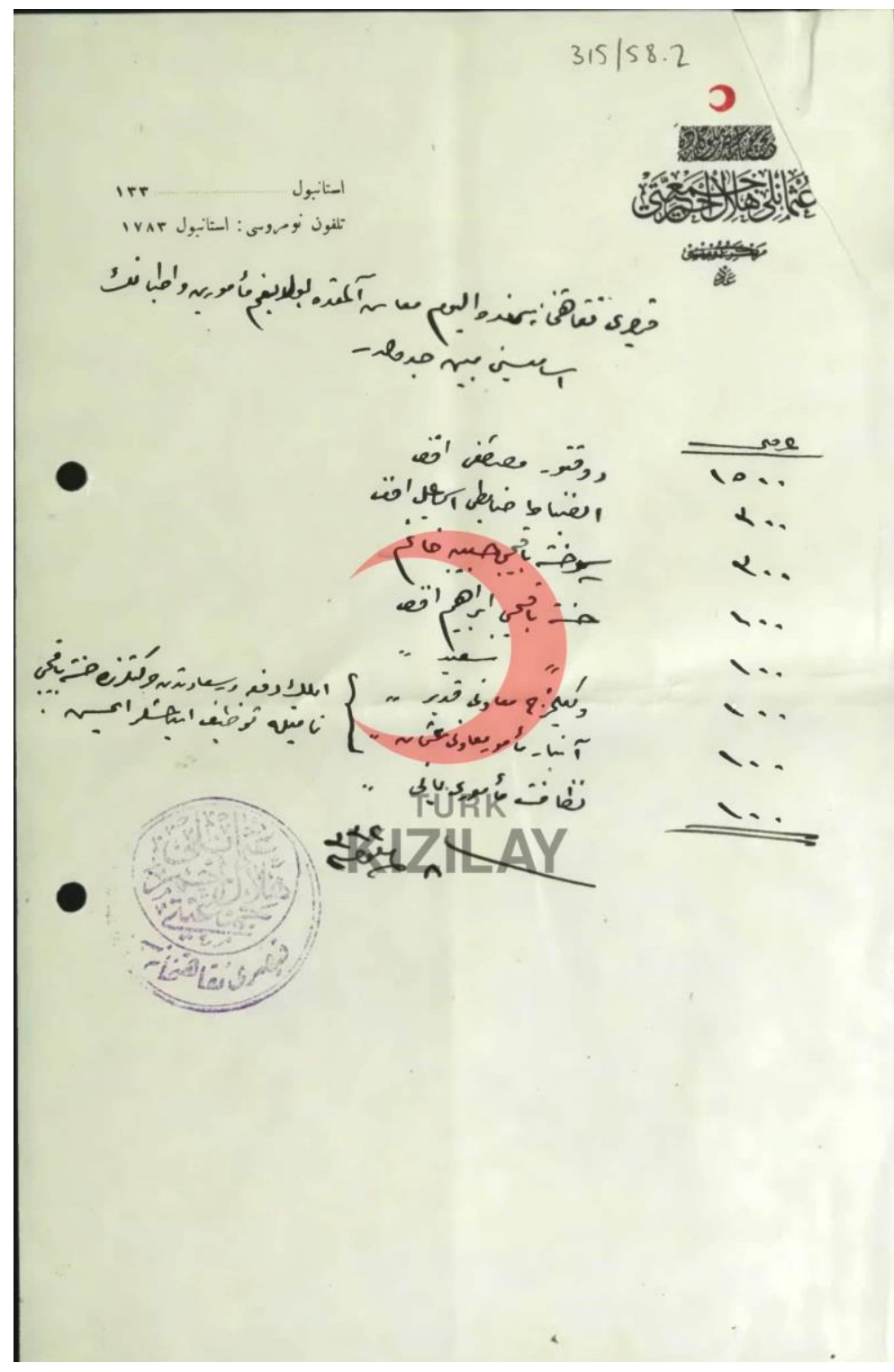

EK-2) Zincidere Nekahethanesi'nin personel listesi (KA, 315/58, lef:2) 


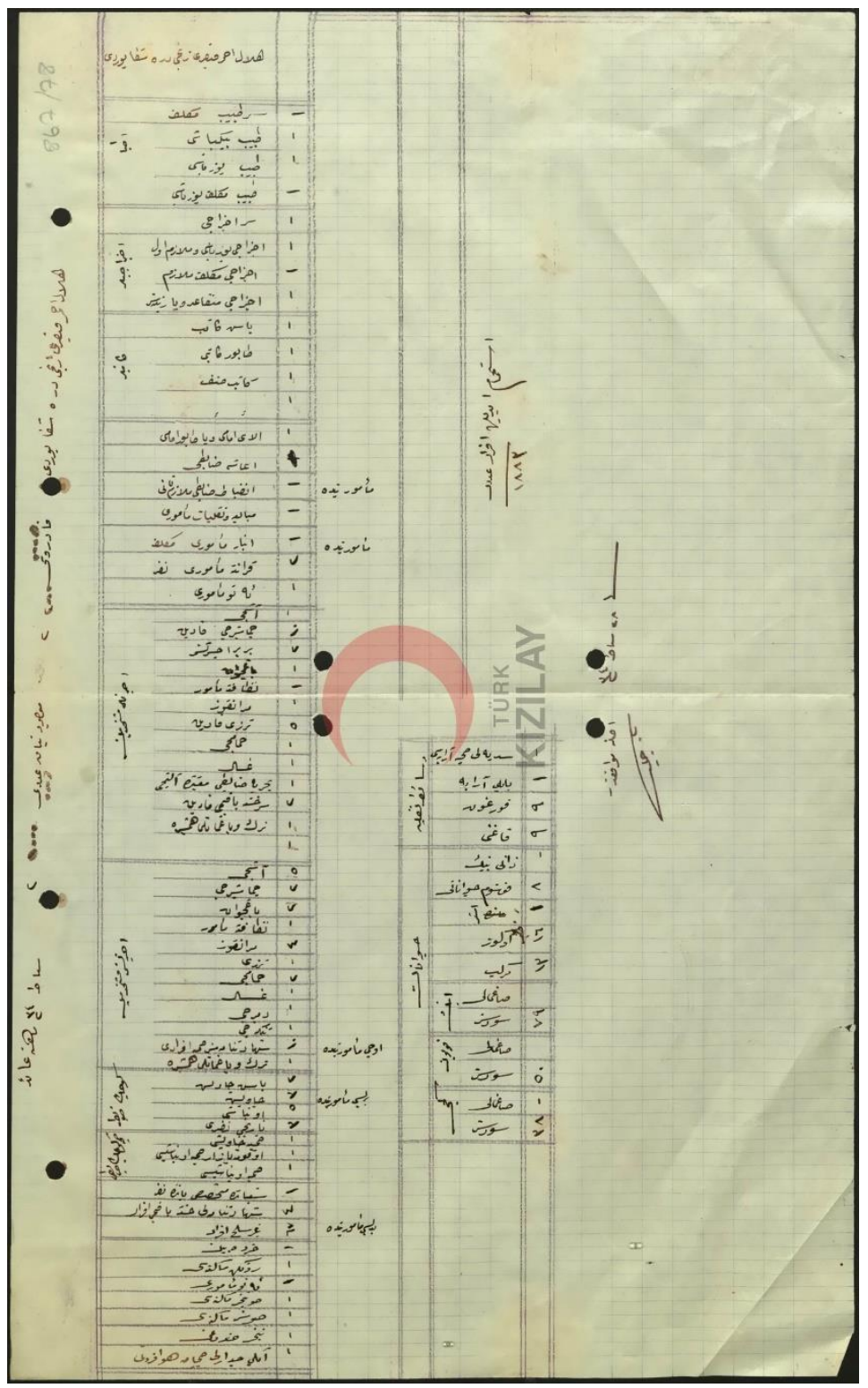

EK-3) Zincidere Şifa Yurdu Kadrosu ve Mevcudiyat Adeti (KA, 867/78)

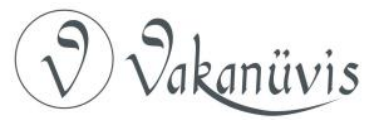




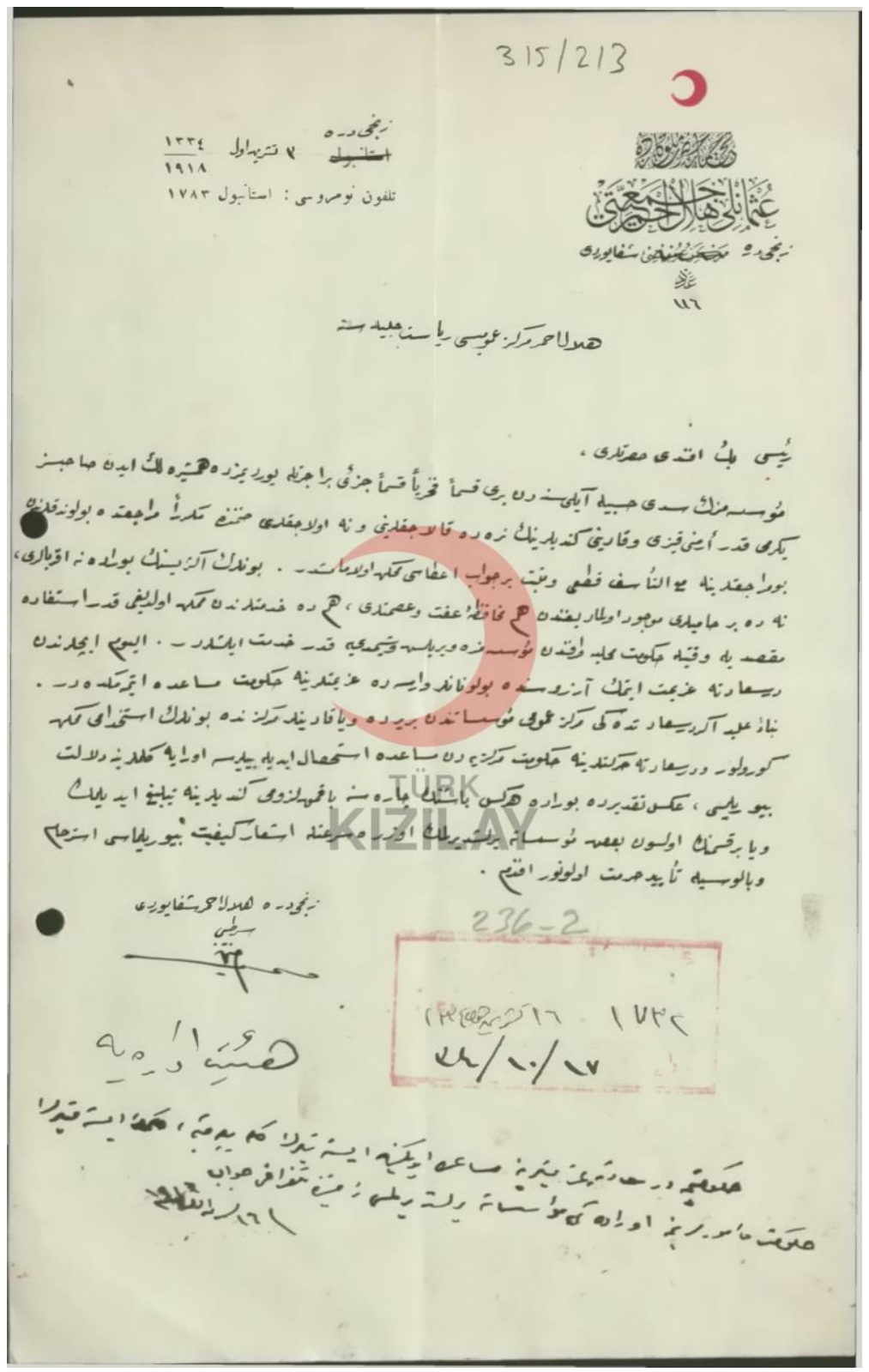

EK-4) Zincidere Şifa Yurdu'nda hastabakıcı olarak çalışan 20 kadar kimsesiz Ermeni kadının durumu (KA, 315/213)

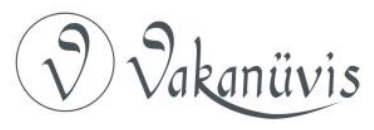




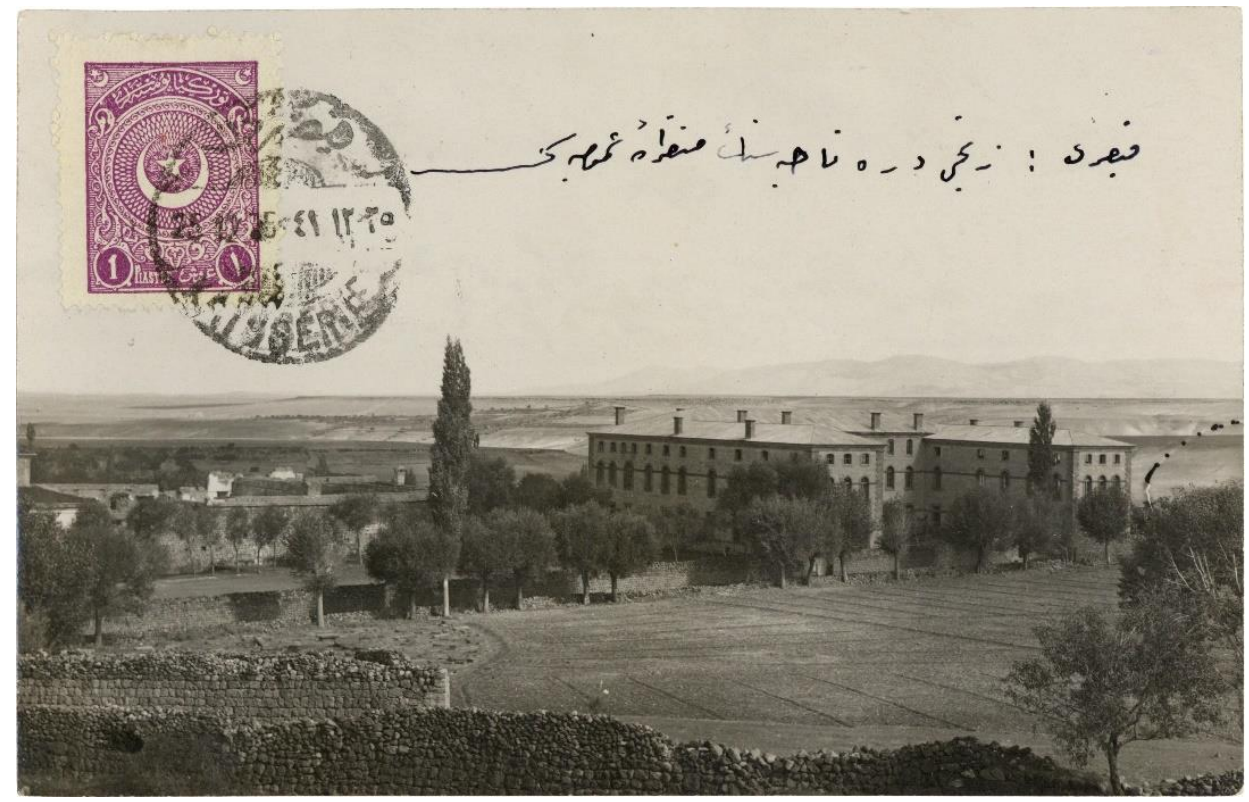

Ek-5) Zincidere Nekahethanesi/Şifa Yurdu'na dönüştürülecek olan Zincidere Karyesi Amerikan Eytamhanesi (SALT Araştırma, HarikaKemali Söylemezoğlu Arşivi https://archives.saltresearch.org/handle/123456789/99214) 